\title{
Women and Whistle-Blowing: Gender in Reporting Channel and Moral Reasoning to Report the Fraud in Procurement Processes in The Government Sector
}

\author{
Dian Fitria Handayani ${ }^{1}$ and Nayang Helmayunita ${ }^{2}$
}

${ }^{1}$ Universitas Negeri Padang, Indonesia

${ }^{2}$ Universitas Negeri Padang, Indonesia

\begin{abstract}
This study aims to examine the effect of gender in reporting fraud in the procurement of goods in government sector. The study employs a 2 x 2- between-subject experimental design with the participant of bachelor's degree of Accounting Student Faculty of Economics, Universitas Negeri Padang. Hypothesis testing used Two-way ANOVA. The Result shows that there are no differences between man and women to report the fraud in procurement. In the other hands, the result shows that women in non-anonymous condition tend to report fraud compared anonymous condition and result also shows that there are differences between reporting channel and moral reasoning in report fraud. This study also not able to prove that women who have high moral reasoning will report fraud in non-anonymous conditions.
\end{abstract}

Keywords: Gender, Reporting Channel, Moral Reasoning and Reporting Intention.

\section{Introduction}

No one can predict someone will be a whistle-blower. The possibility of reporting fraud depends on the situation who fraud perpetrator, what is the risk of reporting, and the impact of fraud. Everyone can be a whistle-blower when they know of fraud. Whistle-blower tend to allow conscience "you will say it when you see it", but fraud will never know until fraud is revealed.

In the governance sector, there is no guarantee unqualified opinion in regional device performance unit (SKPD) free from fraud. Many cases of corruption occur in the government sector that receives an unqualified opinion (WTP). Unqualified opinion issued by The Audit Board of Indonesian (BPK RI) was shielded to deceive public against the corrupt behavior of officials in the governance agencies. case of alleged bribery in ministry of Village, Development of Disadvantaged Regions and Transmigration (Kemendesa), case of alleged bribery procurement Electronic Identity Card (E-KTP) in Ministry of Home Affairs (Kemendagri), Purbalingga Regent as a suspect in an alleged corruption case related to the construction of an Islamic center in the Central Java regency (thejakartapost,com, 2018) is an example of fraud problems that arise in government agencies that have unqualified audit opinions.

The Audit Board of Indonesian (BPK RI) in a press release in June 2018 says that unqualified opinion from BPK RI to ministries, institutions, and local governments do not guarantee corruption. Many factors caused fraud in the governance sector, such as civil servant salaries are classified as low, weak commitment and consistency in law enforcement, low internal supervision mechanisms, weak morals, and ethics. (Hardjapamekas, 2008). Association of Certified Fraud Examiners (ACFE) said that corrupt is a part of a fraud. Based on the corruption perception index 2016 which published on Transparency International, Indonesia scored 37 and ranked 90th out of 176 countries assessed.

In the governance sector, one of the most frequent acts of corruption in the process of procuring goods and services. Based on the release of the KPK (The Corruption Eradication Commission) in 2018, said that the most corruption cases are occurring in the procurement of goods and services which are often carried out "markup" or increased. Based on the complaint records received by the KPK from 2015 to 2018, the KPK received complaints from East Java of 1,790 complaints from whistle-blowers that 345 complaints have been traced as cases of misuse of procurement of goods and services. (antaranews, 2018). This act of cheating can be prevented in various ways. 
Albrech et.al (2014:435) state that fraud can be prevented through two basic factors, first bring up an honest, open culture and support for employees, the second close the opportunity to commit fraud and create legal action for perpetrators of fraud. One step to close the opportunity to commit fraud is to create a system to report fraud.

Whistle-blowing as an act of a person either from an employee or a former employee reveals that there has been an illegal or unethical behavior or action to higher management (internal whistleblowing) or to the authorities outside the organization and the public (external whistle-blowing). While the person reporting the fraud is called a whistle-blower. Whistle-blowers can come from internal parties or members of organizations or external parties outside the community. Bouville (2007) One because that is considered by someone to report or not to report fraud is a reporting system that can guarantee the protection of the complainant. The importance of the protection of witnesses and victims, the Government of Indonesia has established a Law to guarantee the protection of witnesses and victims, namely Law No. 13 of 2006 on the protection of witnesses and victims.

The theory hierarchy of needs by Maslow (1954) states that every individual needs a sense of security. This will relate to the desire to report fraud. A reporting system that can guarantee the confidentiality of the reporter's identity will be a motivation for reporters to report because they feel that their basic needs are met. Rotschild and Miethe (1999) state that whistle-blowing has two opposing views, namely positive views, and negative views. It is said to be positive because it can protect the values of truth which are considered more important than loyalty to the organization, whistle-blowing seen from the negative side is considered a form of betrayal because it has revealed the problems that exist within the organization. This difference in views makes one experience an ethical dilemma in the act of intention to report fraud.

Theory of planned behavior states that a person will act or behave because of an intention. Therefore, the intention of a person has an important role in determining whistle-blowing action. The more you have a strong intention to act, the more likely it is that the intention is carried out in the form of action. Besides that, one of the factors that can influence a person to become a whistle-blower is the factor of morality. Davidson (2009) and Zerema (2011) found there is no significant gender differences in male and female moral intentions. As for Lasova (2012) there is a higher level of moral intention in men than women. Richardson (2014) shows that gender has no significant effect on whistle-blowing action.

Rehg et al., (2008) stated that men are more likely to have the intention to participate in whistleblowing actions, and women are more submissive and less voiced than men in expressing acts of fraud or looking at acts of fraud. Adebayo (2005) states that women will have greater morals than men, exhibit sophisticated moral behavior and as a rule that reduces the amount of sentence relief, and positive disposal for errors compared to men. Rehg et al., (2008) further argued that female whistle blowers act in ways that are different from their female character. As previously observed, the results and findings of the study of gender gaps in whistle-blowing are uncertain. For example, Mesmer-Magnus and Viswesvaran (2005) suggested a somewhat higher tendency for female workers to be a whistle-blower but found that gender had no effect on the intention to blow the whistle.

According to a theory recently presented by Patricia Sellers in an article in Fortune, there are three reasons why women tend to be whistle-blowers rather than men in the face of cheating or injustice. First, women are generally very positive in taking risks. Generally, they "tend to have a small level of tolerance to the company in actions related to ethical violations". Both women are often referred to as "motherhood gene" or have a motherly nature that causes them to express and defend those who are in a weak position even though these actions threaten their position. Third, even though women have worked in even large companies (IBM, GM, Pepsico) women are still considered outsiders in the business world and not influential people in the business world, thus increasing the tendency to express fraud. 
This study examines differences in the intentions of reporting cheating between men and women in the process of procurement of goods and services, given the inconsistent results of research on gender in the intentions of reporting fraud. In addition, this study also wants to find factors that influence a person's intention to conduct whistle-blower actions in the procurement of goods and services in the government. This is done because there are still many acts of fraud and acts of corruption that occur in the process of appeasement in the government sector and this is revealed because there is someone's intention to be a "whistle-blower" since the government passed an anonymous witness protection law. With the existence of an anonymity reporting system, it will be able to guarantee the security of potential reporters of fraud. According to the theory of moral reasoning, the level of one's moral reasoning will affect the individual is doing. At the lowest level of moral reasoning, individuals will act if the action will benefit themselves even if the action may not comply with the norms. While individuals who are at a high level of moral reasoning, individuals will act in accordance with the prevailing norms, even though the actions that must be taken do not guarantee personal security.

Based on the problem above, the research questions are:

1. Are there differences in intentions of reporting between men and women in reporting fraudulent actions in the procurement process in the government

2. Will the type of reporting channel affect interest in reporting fraudulent actions in the government procurement process?

3. Will the level of moral reasoning affect the interest to report fraud in the government procurement process?

Theory of planned behavior (TPB) is a psychological theory that explains the relationship between attitudes and behavior. TPB proves that intention (intention) is more accurate in predicting actual behavior and at the same time can be a proxy that connects actual attitudes and behavior. According to Ajzen (1991), the intention is assumed to be a factor that motivates actions and behavior based on how hard the effort is done by an individual to achieve what is desired.

Ajzen (1991) refers to three beliefs, namely normative beliefs, behavioral beliefs, and control beliefs. besides that, the concept of intention has three independent determinants. The first determinant is the attitude towards behavior (attitude towards behavior), which is a stage where someone evaluates or evaluates whether the behavior is good to do or not. The second determinant is subjective norms (subjective norm), this determinant refers to the perception of perceived social pressure to consider doing a behavior. The third determinant is perceived behavioral control, referring to the ease or difficulty faced to conduct behavior. The better subjective attitudes and norms respond to behavior and the greater the perception of behavior control, then the stronger the individual's intention to consider implementing behavior.

Pfeffer \& Salancik (1978) asserts that whistle blowing involves statements made by members of an organization related to unlawful, corrupt or illegal practices within the scope of organizational management for individuals or authorities who could act. Miceli and Near (1992) designate whistle blowing as actions taken by members of an organization from prohibited, corrupt or dishonest practices in the influence of leaders, communities, organizations or authorities that might lead to change. According to Omojola (2013) whistle blowing has three constant criteria, namely: disclosure of organizational errors to the authorities / authorities; initiation which is an aspiration to avoid damage that can be avoided, and reporting actions carried out anonymously by workers.

Bouville (2007) states that whistle-blowing is an action of an employee (or former employee) to disclose what he believes to be illegal or unethical behavior to higher management / top management (internal whistle-blowing) or to authorities / authorities outside the organization or to the public (external whistle-blowing).

Whistle-blowing system is needed to disclose violations, or unlawful, unethical or immoral acts committed by employees or organizational leaders to the authorities (internal or external), for the realization of ethical business practices in realizing good governance and clean government. 
Complaints from whistle-blowers proved to be more effective in uncovering fraud than other methods such as internal audit or external audit (Sweeney, 2008 in Bagustianto, 2014).

According to Elias (2008) there are two types of whistle-blowing reporting, namely internal whistleblowing and external whistle-blowing. Internal Whistle-blowing occurs when an employee knows of cheating by another employee then reports the fraud to his supervisor. External Whistle-blowing occurs when an employee knows the fraud committed by the organization and then informs the public because the fraud will harm the community. Someone tends to do internal whistle-blowing first, before revealing the fraud to the public. But they will reveal the fraud they know if the internal party does not respond or is unable to overcome the problem of fraud.

Becoming a whistle-blower is not an easy matter because the whistle-blower will face an ethical dilemma between having to report or let the fraud remain hidden (Bagustianto, 2014). This is a big challenge for the reporting party, because it is likely that he will be considered a traitor and has violated the norms of organizational loyalty. Therefore, protection for whistle-blowers must be of special concern. This is necessary to increase the desire of each party to report fraud in the organization.

Unclear legal protection that will be obtained by the whistle-blower makes the whistle-blower increasingly reluctant to report fraud in the organization. They consider the impact they will face after they report the fraud they know. Whether this will protect the organization where it works or even threaten their safety and position in the organization. Although the protection of the whistle-blower is implicitly regulated in Law No.13 of 2006 concerning Witness and Victim Protection and the Supreme Court Circular Number 4 of 2011 concerning the Treatment of Whistle-blowers and Collaborating Witnesses (LPSK, 2011). In addition, the Guidelines for Reporting and Violation System (SPP) or Whistle-blowing System (WBS) issued by the National Committee on Governance Policy (KNKG) on November 10, 2008 stated that a good violation reporting system provides facilities, namely: first, reporting channel facilities (telephone, letter, email) or an independent, free and confidential Ombudsman. Second, the protection of the confidentiality of the reporter's identity. Third, protection against retaliation from the reported party or organization. Protection from pressure, postponement of promotion, dismissal, legal action, property, to physical action. Fourth, information on the implementation of follow-up, in the form of when and how and to which institution the followup was submitted.

The Theory of Hierarchy of Needs was first explained by Abraham Maslow in 1954. This theory is the most famous classical motivation theory. In this theory, Maslow stated that there were five basic needs needed by humans, they are:

a. Physiological Needs, which are the most basic needs of humans. Among others ; fulfillment of oxygen needs and gas exchange, liquids (drinks), nutrition (food), elimination, rest and sleep.

b. Security and protection need, divided into physical protection and psychological protection. Physical protection, including protection from threats to the body and life such as accidents, diseases, environmental hazards, etc. Psychological protection, protection from threats of new or foreign events or experiences that can affect a person's mental condition.

c. Love, which is the need to have and have, to give and receive love, warmth, friendship, and family. d. The need for self-esteem and feelings valued by others and recognition from others.

e. The need for self-actualization, this is the highest need in the Maslow hierarchy, in the form of the need to contribute to other people or the environment and achieve full potential.

Rehg et al., (2008) argued that social role theory has a gender relationship and the danger of whistleblowing, predicting that more men than women have the intention to participate in whistle blowing. Women are more submissive and less voiceless than men, even in exposing or revealing acts of corruption. Adebayo (2005) asserts that women will display morals that are better in obeying rules than men. Rehg et al., (2008) further argued that female whistle-blowers act in ways that are different from their female character. As previously observed, the results and findings of the study of gender gaps in whistle blowing are uncertain. For example, Mesmer-Magnus and Viswesvaran (2005) 
suggested a somewhat higher tendency for female workers to become whistle-blowers but found that gender had no effect on whistle-blowing intentions. Davidson (2009) and Zerema (2011) found no significant gender differences in male and female moral intentions. As for Lasova (2012) there is a higher level of moral intention in men than women.

Richardson (2014) shows that gender does not have a significant effect on the intentions of reporting fraud. Omojuyigbe (2009) and Sloan (2011) assert that men tend to be in a higher rank position than women in organizations, women have a lower probability than men who participate in whistle blowing. Beard (2007) found that female whistle-blowers face greater levels of social abuse than whistle-blowers. Women who testify about serious violations or bad behavior that affect survival have a higher level of retribution, while men do not. Again, some people assume that female whistleblowers act in irregular fashion with their positions. In whistle blowing on grave misconducts or advanced violators, whistle blowing goes further in conflict with a role that is suitable for women, so they are considered worthy of retribution.

H1. there are differences between woman and man in intention to reporting the fraud in governance procurement process.

Type of reporting channel in intention reporting fraud.

$\mathrm{H} 2$. When the reporting channel available is non-anonymous, women will be more likely to report fraud that occurs than men

H3. In an anonymous condition, the intention to report government procurement fraud will be higher than non-anonymous conditions

Moral Reasoning and Employee Interest to Report Fraud.

Psychology of moral reasoning is based on Piaget's theory $(1932,1966)$. This theory assumes that cognitive and moral development go hand in hand, and that cognitive schemes and structures are innate, universal, invariant, hierarchical and culturally universal.

Kohlberg (1969) made an important contribution to the theory of moral development by continuing Piaget's theory that had never been completed. Kohlberg's research shows the moral development of universal development. Kohlberg makes a sequence that defines a series of cognitive levels and is somewhat like stairs. In each of the three levels of ethical assessment there are two stages of development, resulting in a total of six conditions as follows:

One aspect of the study that is most closely related to this research is the relationship between moral reasoning and the whistle-blowing phenomenon. Whistle-blowing is defined as "disclosure by members of the organization (former and present) about the existence of illegal, immoral, or illegal practices under the control of their superiors, to people or organizations that may be able to take action" (Near and MAceli 1985). Research conducted by Arnold and Ponemon (1991) shows that internal auditors with relatively low levels of moral reasoning tend not to report fraud, and this is especially true if there is potential retaliation. This finding is supported by Kohlberg's (196) theory that individuals with lower levels of moral reasoning will make the decision to do the right thing to avoid punishment (stage 1) or to serve their own interests (stage 2).

If the individual is in the conventional stage (stage 1 and stage 2), knowing the fraudulent actions that occur and the possibility of retaliation from the perpetrators of fraud, the individual tends to make more selfish decisions, so the choices to be made are likely to be not to disclose fraud. Whereas individuals who are in the conventional stage, when faced with the circumstances of fraud that occur within the organization, will be more likely to see in advance whether the action is common or not, if the fraud is common, the individual will not report, because it uses the assumption that this is a common thing in the organization.

Unlike individuals who are at the post-conventional stage, there are these stages that ethical judgments have been internalized in the individual, so that the decision to be taken is not a decision that only benefits themselves, but a decision that is truly in accordance with existing rules and norms. So that if an individual or employee who has a high level of moral reasoning is in a situation of knowing there is an act of fraud, the decision to be taken is to report the perpetrator of fraud to the 
authorities, even though there is a possibility of getting threats from the perpetrators of fraud. Based on the description above, the next hypothesis is proposed

H4 when individuals have a high level of moral reasoning, the intention to report fraud in the procurement process will be higher than individuals who have a low level of moral reasoning

H5: When conditions are non-anonymous, women with a high level of moral reasoning will tend to report fraud that occurs compared to low levels of moral reasoning.

\section{Research Methodology}

Subjects in this study were students of 5th and 7th semester students in the S1 Accounting program at UNP FE. The subject of this study was chosen because the 5 th and 7 th semester students were and had taken Auditing and Business Ethics courses, so that students were able to do the assignments. Besides that, the selection of students as the subject of research because based on the psychology literature shows that students can process the same information with professional individuals in psychology experiments (Nahartyo and Utami, 2015).

This research was conducted through a $2 \times 2$ between subject design experiment. The experiment was designed by doing two treatments in two different conditions, namely moral reasoning (high / low) and the condition of non-anonymous and anonymous reporting channels. Each subject is randomly placed into one of the treatment conditions. This is done to reduce the influence of confounding variables that can reduce the internal validity of research results (Ghazali, 2008). So, each subject receives one of the possible manipulation combinations distributed in two case versions, and with the same number of distributions from each version. It is hoped that this will result in the number of subjects for each combination of the same experimental treatment. Table 1 presents the experimental design. Two cases designed are the first case of a combination of anonymous reporting channel manipulations. The second case is the manipulation of non-anonymous reporting channels.

Table 1. Design Experiment $2 \times 2$.

\begin{tabular}{|l|l|l|l|}
\hline \multirow{2}{*}{ (treatment) } & \multicolumn{2}{|l|}{ Reporting Channel } \\
\cline { 3 - 4 } $\begin{array}{l}\text { Moral } \\
\text { Reasoning }\end{array}$ & High & cases 1 & cases 2 \\
\cline { 2 - 4 } & low & cases 3 & cases 4 \\
\hline
\end{tabular}

Each subject is randomly placed into one of four treatment conditions. Each subject is given one case from four available case versions. So, each subject receives one of the possible combinations of manipulations. It is hoped that this will result in almost the same number of subjects for combination experimental treatments. Subjects filled out a background questionnaire designed to gather demographic, educational and work information before working on experimental tasks. After completing the filling in of the participant's data, the subject is briefed on the case and then does the assignment and answers the questions in the case as well as the manipulation check questions.

Research Instruments.

a. Instrument reporting Channel and intention reporting Fraud.

This research instrument refers to research conducted by Kaplan et.al (2012) and Nasution (2016), with several adjustments related to the context of this study. This research instrument uses two cases. In each case the participant will act as a civil servant who works in the City Government SKPD X. All cases illustrate that there is an order from the SKPD leader to make payments to partner companies that did not complete procurement and installation of traffic signs until 30 September which is the deadline for the contract. In cases that test the effect of reporting violation channels on interest to report fraud in the procurement of goods / services, there will be an information section explaining the work program on corruption prevention of City X Government. For non-anonymous reporting channels, in the case there is an explanation that to report corruption indications must include identity. 
As for anonymous reporting channels, in case there is an explanation that to report indications of corruption can use a website-based online application where each reporter can use his pseudonym. After reading the case given, at the end of the research instrument the participant will be asked to give his preference whether he is interested or not to report fraud in the procurement of goods / services previously described. Furthermore, there are also manipulation questions in the research instrument that must be answered by participants. The question requires participants to choose one of two statements that describe the conditions and situations that best suit the case received by each participant.

b. Instrument defining issued test (DIT)

This instrument is in the form of an ethical dilemma case. Each scenario is followed by twelve statements representing the Kohlberg stage 2-6. After giving an assessment of the considerations in the twelve statements, participants were asked to rank 4 statements that were most important to them in making decisions. The four statements are then matched with their previous answers on the consideration of twelve statements. The score is given for each statement that matches stage 5-6. The calculation results of stage 5 and 6 are P-scores (post-conventional scores) which represent the level of intention of individual reporting. The P-score is calculated by adding each score from all four scenarios and dividing it by 0.40 .

\section{Result and Discussion}

To find out the subject's understanding of the case manipulation provided there were four manipulation questions proposed at the end of the experiment. Participants are deemed to have passed the manipulation check if they answer the check manipulation question correctly in accordance with the case received. Inaccurate answers were excluded from the analysis because participants were deemed not to understand the experimental material provided.

The results of the examination of the experiment participants' manipulation were as many as 40 participants who did not pass the manipulation of a total of 155 participants who participated in the experiment. This happened because the participants did not understand the case illustration provided, so the participants answered the manipulation question not in accordance with the case given.

Furthermore, before further analysis, randomization data was tested first. Randomization is an important element in experimental research. Randomization is done by placing subjects into the experimental group and the control group randomly without paying attention to the factors inherent in the subject in order to ensure independence that does not pay attention to demographic characteristics, so that the differences that occur are purely caused by the given manipulation (Nahartyo and Utami, 2016) .

Randomization testing was done by Chi-Square analysis to show that there was no difference between the groups of subjects experimented based on. Based on the results of Chi-Square testing it can be concluded that there is no significant difference between each group due to the sig value. Pearson chi-square of each characteristic is greater than $0.05(\mathrm{p}>0.05)$. The following details of the results of the randomization testing were carried out. The results of the chi-square randomization test at the level of 5th semester students and 7th semester students showed the results that there were no significant differences between groups ( sig. $0.917 ; p>0.05$ ) so that the test could be continued The variance homogeneity test is intended to show that two more groups of sample data come from populations that have the same variance. The variance homogeneity test uses an $\mathrm{F}$ test conducted in both groups, namely with an environmental perspective and without an environmental perspective. In this study the homogeneity of variance carried out using Leaven's Test showed that the p-value was $0.394>0.05$. The test results show the variance between groups statistically has the same variant so that the assumption of ANOVA usage can be fulfilled.

Hypothesis testing is done using two-way anova. The first hypothesis examines the difference between women and men in reporting fraud in the government procurement process in reporting fraud. Based on the Anova test results, found evidence that the value of sig. is $0.249>0.05$ so the first 
hypothesis in this study is not supported. The results of this study in line with Richardson's research (2014) show that gender does not have a significant effect on whistle-blowing action. The same results also shown by Fapohunda's research (2016) found evidence that there are no significant gender disparities in the social and emotional dynamics of influencing whistle blowing intentions. The female employees were as dissuaded as the male employees from blowing the whistle

Furthermore, $\mathrm{H} 2$ tests the difference when the reporting type available is non-anonymous, women will be more likely to report fraud that occurs compared to men. Based on the test results found evidence of sig value. $0.019<0.005 . \mathrm{M}=5,799$; $\mathrm{SD}=0.457$ ) so this research hypothesis is supported. The results of this study reinforce Tilton's (2018) research, suggesting that women are more likely to be specific and important type of external contact than men.

$\mathrm{H} 3$ tested the reporting report when the anonymity condition was hypothesized that the intention to report government procurement fraud would be higher than the non-anonymous condition. based on the results of statistical tests found evidence that the value of sig $F=4.048$; sig. $0.047<0.05$, so the results of this study are supported. The results of this study are in line with the previous research and strengthen the results of previous studies.

H4 compared the high level of moral reasoning with a low level of moral judgment in the intention of reporting fraud. Based on the results of hypothesis testing, there is evidence that sig is $0.00<0.05$, so the hypothesis is supported.

H5 compares the reporting channel, moral and gender level of reporting in reporting fraud, and found evidence that the sig value is $0.905<0.05$, so the hypothesis in this study is not supported. The results of this study are supported by the psychological theory of planned behavior (TPB) which states that in decision-making the decision-making attitude is influenced by personal beliefs about what is considered right and what is considered wrong in accordance with subjective norms (Ajzen's, 1985 )

\section{Conclusion}

Based on the results of the data analysis and discussion of the previous chapter, the following conclusions can be drawn:

1. There is no significant difference between man and women in reporting fraud.

2. When fraudulent reporting conditions in the form of non-anonymous women will report cheating compared to men in non-anonymous conditions.

3. Conversely, when reporting fraud is anonymous, men will tend to report cheating rather than women.

4. There are significant differences in moral reasoning in the intention of reporting fraud.

5. There are no significant differences in the reporting channel, level of moral reasoning and gender in fraud reporting actions.

In this study there are some limitations that cannot be avoided and can affect the results of the study. These limitations are:

1. Limitations of research related to the method are not considered the influence of information sources that might be taken into consideration as explained by Fisher (1996).

2. The experimental case design in this study was designed simply so that it was not able to capture the reality of fraud.

3. Experiments carried out in the afternoon and afternoon after the lecture ended, allowing participants to experience fatigue while doing experimental tasks.

The suggestions that can be given based on the results of this study are as follows:

1. Further research can use a wider sample and participants who are directly involved in the procurement process, so that the level of generalization can be better.

2. As revealed in the limitations of research regarding the level of understanding of different participants. Subsequent research can provide advance understanding of the concept of whistleblowing 
3. Further research can use survey methods on SKPD or people who have experience in procurement of goods, so that the results of the study can be compared.

\section{References}

Adebayo, D. O. (2005). Gender and attitudes toward professional ethics: A Nigerian police perspective. African Security Review, 14(2), 93-100.

Ajzen, Icek. 1991. The Theory of Planned Behaviour. Organizational Behaviour and Human Decision Processes. Vol.50: 179-211.

Albrecht, Conan, Mark F. Zimbelman, W. Steve Albrecht, dan Chad O. Albrecht. 2014. Akuntansi Forensik: Forensic Accounting. Salemba Empat. Jakarta.

Beard, Deborah (2007). Retaliation: Unlawful, unethical, or just to be expected? Strategic Finance, $89(2), 32-38$.

Bouville, Mathieu. 2007. Whistle-Blowing and Morality. Journal of Business Ethics. 2008 (81): 579 585.

Bouville, Mathieu. 2007. Whistle-Blowing and Morality. Journal of Business Ethics. 2008 (81): 579 585.

Davidson, L.M. (2009) Professional Ethics and Complicity in Wrongdoingee, Journal or Markets and Morality, 11 (1): 93- 1000.

Fapohunda, Tinuke. (2016). Gender: Precursor of Whistle Blowing Intentions and Reprisals. International Journal of Research in Humanities and Social Studies. Volume 3, Issue 12,December 2016, PP 19-27

Fapohunda, Tinuke. M (2010). Gender : Precursor of whistleblowing intention and reprisals. International Journal of research in humanities and social studies, Vol 3(12).

Frederick D (2015). Woman as Whistleblowers: Does Gender Affect Retaliation?. Blankrome Publication.

Ghozali, Imam. 2008. Desain Penelitian Eksperimental: Teori, Konsep dan Analisis Data dengan SPSS 16.0. Universitas Diponegoro. Semarang.

Gregory A. Liyanarachchi and Ralph Adler (2010). Accountants' whistle-blowing intentions: The impact of retaliation, age, and gender. Department of Accountancy and Business Law, Working paper series. University of Otago.

Hardjapamekas, Erry Riyana. 2008. Melawan Korupsi Tugas Kita Bersama. http://www.fokal.info/fokal/arsip-hukum/365.html.

http://www.thejakartapost.com/news/2018/06/05/purbalingga-regent-arrested-over-allegedgraft.html.

https://jatim.antaranews.com/berita/250494/kpk-modus-korupsi-terbanyak-sektor-pengadaanbarang-jasa. Jakarta.

Kaplan, Steven E dan Joseph J.Schultz. 2007. Intentions to Report Questionable Acts: An Examination of the Influence of Anonymous Reporting Channel, Internal Audit Quality, and Setting. Journal of Business Ethics. Vol. 71: 109-124.

Kaplan, Steven E. dan Stacey M. Whitecotton, 2001. An Examination of Auditors' Reporting Intentions When Another Auditor is Offered Client Employment. A Journal of Practice and Theory. Vol. 20 (1): 45-63.

Kaplan, Steven E., Kurt Pany, Janet A. Samuels dan Jiang Zhang. 2009. An Examination of The Effects Of Procedural Safeguards on Intentions to Anonymously Report Fraud. Auditing: Journal of Practice and Theory. Vol 28 (2): 273-288.

Kaplan, Steven E., Kurt Pany, Janet Samuels dan Jiang Zhang. 2012. An Examination of Anonymous and Non-Anonymous Fraud Reporting Channels. Advances In International Accounting. Vol. 20: 88-95. 
Kohlberg, L. 1969. Stage and Sequence: The Cognitive-Development Approach Moral Action to Socialization. In D. A. Goslin (Ed). Handbook of socialization theory and research (pp.347480). Chicago: RandMcNally.

Komite Nasional Kebijakan Governance. 2008. Pedoman Sistem Pelaporan Pelanggaran- SPP (Whistle-Blwoing System-WBS).

Lasova, M.L. (2012) Decision-making process of internal whistleblowing behavior in China: Empirical evidence and implications. Journal of Business Ethics, 88:25-41.

Liyanarachchi, Gregory dan Chris Newdick. 2009. The Impact of Moral Reasoning and Retaliation on Whistle-Blowing: New Zealand Evidence. Journal of Business Ethics. Vol. 89: 37-57.

Miceli, M.P. Near, J.P. and Schwenk. C.P. (1999). Who blows the whistle and why? Industrial and Labor Relations Review, 45, 113-30.

Miethe, Terance D. (1999) Whistleblowing at Work: Tough Choices in Exposing Fraud, Waste and Abuse on the Job. Boulder, Colo.: Westview Press, 1999.

Nahartyo, E., dan Utami, I. 2016. Panduan Praktis Riset Eksperimen. Indeks, Jakarta.

Nahartyo, Ertambang. 2012. Desain Dan Implementasi Riset Eksperimen. UPP STIM YKPN.

Omojuyigbe, P.N (2009) Gender Relations and Discrimination in Nigeria Police Force, Lagos, Centre for Law Enforcement Education.

Peraturan Pemerintah Republik Indonesia Nomor 71 Tahun 2000 Tentang Tata Cara Pelaksanaan Peran Serta Masyarakat dan Pemberian Penghargaan dalam Pencegahan dan Pemberantasan Tindak Pidana Korupsi. 21 Agustus 2000. Tambahan Lembaran Negara Republik Indonesia Nomor 3995.

Peraturan Presiden Republik Indonesia Nomor 4 Tahun 2015. Perubahan Keempat Atas Peraturan Presiden Nomor 54 Tahun 2010 Tentang Pengadaan Barang/Jasa Pemerintah. Lembaran Negara Nomor 5 Tahun 2015. Jakarta.

Putri, Ceasar Marga. 2012. Pengujian Keefektifan Jalur Pelaporan Pada Structural Model Dan Reward Model Dalam Mendorong Whistleblowing: Pendekatan Eksperimen. Simposium Nasional Akuntansi 15. Tanggal 11-15 Oktober 2012. Banjarmasin.

Rehg, M. T., Miceli, M. P., Near, J. P., \& Van Scotter, J. R. (2008). Antecedents and outcomes of retaliation against whistleblowers: Gender differences and power relationships. Organization Science, 19(2), 221-240.

Richardson, W.E (2014) Sense and nonsense about culture and climate. In N.M. Ashkanasy, C. P. M. Wilderom, and M. F. Peterson (Eds.), Handbook of organizational culture and climate (pp.xxiii-xxx). Thousand Oaks, CA: Sage.

Sarbanes-Oxley Act Section 301. Public Law 107-204 July 30, 2002. USA.

Siaran Pers. 2011. Opini WTP Tidak Menjamin Tidak Ada Korupsi. Badan Pemeriksa Keuangan. Jakarta.

Sloan, M.K. (2011) Whistleblowers: Truth, justice, and the American way. Journal of Applied Management and Entrepreneurship 9(4), 120-132.

Tilton, Clare (2018). Woman and Whistleblowing: Exploring Gender Effects in Policy Design. Columbia Journal of Gender and Law.

Tuanakotta, Theodorus M. 2010. Akuntansi Forensik dan Audit Investigatif. Salemba Empat.

Undang-Undang Nomor 30 Tahun 2002 Tentang Komisi Pemberantasan Tindak Pidana Korupsi. 27 Desember 2002. Lembaran Negara Republik Indonesia Tahun 2002 Nomor 137. Jakarta.

Undang-Undang Nomor 13 Tahun 2006 Tentang Perlindungan Saksi dan Korban. 11 Agustus 2006. Lembaran Negara Republik Indonesia Tahun 2006 Nomor 64. Jakarta.

Winardi, Rijadh Djatu. 2013. The Influence of Individual and Situational Factors on Lower-Level Civil Servants' Whistle-Blowing Intention in Indonesia. Journal of Indonesian Economy and Business. Vol. 28 (3): 361-376..

Zerema, H.P. (2011) The difficulties of whistle blowers finding employment. Management Research News, 24, 97-100. 